\author{
MAŁGORZATA WERONIKA CZACHOR \\ Instytut Języka Polskiego PAN, Kraków \\ ORCID: 0000-0003-1443-0637
}

\title{
Dystrybucja polskich imiesłowów: styl funkcjonalny i długość zdania
}

\section{Wstęp}

Temat nacechowania stylistycznego imiesłowów przewija się w polskiej literaturze od dziesięcioleci, nie był jednak do tej pory omawiany jako oddzielna całość. Celem artykułu jest kwantytatywna analiza występowania imiesłowów przysłówkowych i przymiotnikowych dla dwunastu ${ }^{1}$ stylów języka polskiego wyróżnionych w Narodowym Korpusie Języka Polskiego (NKJP) oraz zbadanie czynników warunkujących taką, a nie inną dystrybucję; szczególną uwagę poświęcam relacji pomiędzy długością zdania a częstością występowania imiesłowów.

Imiesłowy przymiotnikowe to formy pośrednie pomiędzy czasownikiem a przymiotnikiem, a imiesłowy przysłówkowe - pomiędzy czasownikiem a przysłówkiem. Imiesłowy przymiotnikowe dzielimy na czynne (np. robiacy) i bierne (np. robiony), a przysłówkowe na współczesne (np. robiąc) i uprzednie (np. zrobiwszy). Oprócz imiesłowów przysłówkowych istnieją także tzw. quasi-imiesłowy przysłówkowe (frazeologizmy imiesłowowe); konstrukcje z nimi przypominają budową równoważniki zdań z imiesłowem przysłówkowym współczesnym lub uprzednim; nie obowiązuje jednak w ich wypadku reguła tożsamości podmiotu (aktanta) ani względnej relacji czasowej, wyrażającej odpowiednio równoczesność lub następstwo zdarzeń. Przykładami frazeologizmów imiesłowowych są takie związki wyrazowe jak szczerze mówiąc, prawdę powiedziawszy.

Tematem artykułu jest dystrybucja imiesłowów oraz (pobocznie) quasi-imiesłowów w różnych stylach języka polskiego. Styl funkcjonalny to według Stanisława Gajdy

${ }^{1}$ Czy też trzynastu, gdyż ,literaturę piękną” podzieliłam na dwie kategorie w zależności od daty publikacji tekstu, żeby wzbogacić analizę o elementy diachroniczne (więcej informacji s. 6). 
(2012b: 62) „społecznie uświadamiany, wewnętrznie scalony i funkcjonalnie uwarunkowany zespół środków komunikacyjnojęzykowych”. Style w takim ujęciu są powiązane z funkcją tekstu i zewnętrzną sytuacją komunikacyjną. W artykule posługuję się typologią stylistyczną zastosowaną w korpusie NKJP, która nie jest czysto funkcjonalna. Jak piszą Rafał Górski i Marek Łaziński (2012: 15), podział na typy w NKJP to „przecięcie tradycyjnych podziałów stylistycznych i gatunkowych. Wynika on $\mathrm{z}$ inherentnych cech struktury tekstu - stylistycznych lub gatunkowych, czasem - lecz nie często - implikowanych przez poruszaną tematykę, lecz zasadniczo od podziału tematycznego niezależnych". Wyróżniane są takie style/typy, jak: internetowy (interaktywny i nieinteraktywny), publicystyczny, urzędowy, literacki itp. (dokładny opis w sekcji 3.1). W artykule pada również określenie „rejestr”. Używam go jednak w odniesieniu do poziomu formalności języka, co jest tylko jednym z wielu możliwych rozumień tego terminu.

$\mathrm{W}$ artykule omawiam po kolei cztery przeprowadzone przeze mnie badania. Badania 1 i 2 pozwoliły opisać dystrybucję imiesłowów w stylach funkcjonalnych. Badania 3 i 4 miały na celu zweryfikowanie hipotezy, że istnieje zależność pomiędzy liczbą zdań długich w danym stylu a częstością występowania w nim imiesłowów. Hipotezę tę omówię poniżej. Dane do wszystkich badań zaczerpnęłam z NKJP.

W Badaniu 1 badam dystrybucję imiesłowów przymiotnikowych i przysłówkowych w poszczególnych stylach języka polskiego.

Ponieważ jednak NKJP nie rozróżnia pomiędzy imiesłowami przysłówkowymi sensu stricto a quasi-imiesłowami, czyli frazeologizmami, postanowiłam przeprowadzić Badanie 2, w którym wyodrębniam spośród analizowanych w poprzednim kroku imiesłowów przysłówkowych dane odnoszące się do quasi-imiesłowów. Sprawdzam, do jakiego stopnia quasi-imiesłowy modyfikują wyniki Badania $1^{2}$.

W zagadnieniu dystrybucji imiesłowów interesowało mnie nie tylko pytanie ,jak?”, ale i „dlaczego?”. W związku z tym w dalszej części artykułu omawiam wyniki Badań 3 i 4, które miały na celu zweryfikowanie wzmiankowanej wyżej hipotezy, którą teraz omówię nieco dokładniej. Zakłada ona, że konstrukcje imiesłowowe mają cechę, która czyni je szczególnie użytecznymi przy tworzeniu rozbudowanych zdań o dużej liczbie predykatów. Otóż pozwalają one na wyrażenie treści w sposób skondensowany. Imiesłowy przymiotnikowe umożliwiają przekształcenie zdania względnego w grupę nominalną - w przypadku zdania jednokrotnie złożonego taka transforma wygląda nieraz jak niepotrzebne udziwnienie, ale w przypadku zdań wielokrotnie złożonych redukcja liczby członów podrzędnych bywa pożądana, dlatego że może uczynić zdanie bardziej przejrzystym. Z kolei posłużenie się imiesłowami przysłówkowymi nie pomniejsza co prawda liczby członów podrzędnych, lecz pozwala na zróżnicowanie

${ }^{2}$ Anotacja korpusowa nie uwzględnia również stopnia adiektywizacji imiesłowów przymiotnikowych. Rozdzielenie imiesłowów przymiotnikowych i przymiotników wymagałoby jednak manualnego przeglądu wszystkich użyć określonych w korpusie jako imiesłowy i przeprowadzenia ich wtórnej, ręcznej anotacji, tak więc $\mathrm{w}$ tym badaniu ten aspekt został pominięty. 
składniowe struktury zdań wielokrotnie złożonych i wyeliminowanie niektórych spójników. Zatem skrótowość i „pakowność” imiesłowów umożliwiałyby ekonomizację treści w obrębie rozbudowanej, wielopredykatowej jednostki zdaniowej oraz zróżnicowanie jej struktury w celu uniknięcia powtórzeń. To zaś mogłoby pośrednio przekładać się na różnorodną dystrybucję imiesłowów w tekstach w zależności od ich stylu i funkcji. Badanie 3 dotyczyło związku pomiędzy długością zdania a prawdopodobieństwem, że dowolne słowo w zdaniu będzie imiesłowem (w celu sprawdzenia, czy zależność pomiędzy długością zdań a częstością występowania w nich imiesłowów w ogóle istnieje), a Badanie 4 służyło sprawdzeniu, czy zachodzi korelacja liniowa pomiędzy średnią długością zdania w stylach a frekwencją imiesłowów w stylach, czyli czy omawiana zależność - jeśli istnieje - przekłada się jakoś na dystrybucję w stylach funkcjonalnych.

\section{Imiesłowy a styl: stan badań}

W literaturze przedmiotu dominuje pogląd, że imiesłowy przysłówkowe są charakterystyczne przede wszystkim dla stylu literackiego. Maciej Grochowski (1984: 236) pisał: „Używanie konstrukcji imiesłowowych [z imiesłowem przysłówkowym - M.C.] (zwłaszcza imiesłowu uprzedniego) jest cechą właściwą dla tzw. stylu pisanego (książkowego)". Henryk Wróbel (1975: 16) czyni podobne spostrzeżenie, z tym że obejmujące wszystkie imiesłowy czynne, czyli także imiesłów przymiotnikowy czynny. Zwraca uwagę na opcjonalność imiesłowów czynnych: „Język może obejść się bez konstrukcji imiesłowowych, co widać w odmiance mówionej języka ogólnopolskiego i w bliskich polszczyźnie ogólnej systemach gwarowych; konstrukcje imiesłowowe są rysem charakterystycznym odmianki literackiej języka polskiego”. Wyraża też przypuszczenie, że posłużenie się imiesłowem przysłówkowym współczesnym o funkcji akcesoryjnej stanowi często zabieg wyłącznie stylistyczny, mający na celu zróżnicowanie struktury zdania o wielu orzeczeniach - zjawisko to można zaobserwować np. w publicystyce (Wróbel 1975: 45).

Niektóre opracowania poprawnościowe ostrzegają wręcz przed nadmiernym użyciem imiesłowów przysłówkowych nawet w języku pisanym, por. Anna Wierzbicka, Piotr Wierzbicki (1968: 91). Reguła ta miałaby tyczyć się w szczególności imiesłowów uprzednich (zob. Klebanowska 1982).

Nieco inaczej naświetlają to zagadnienie Krystyna Bojałkowska (2010: 20) i Hanna Jadacka (2005: 186), które akcentują różnicę stylistyczną pomiędzy imiesłowami współczesnymi i uprzednimi. H. Jadacka twierdzi, że imiesłowy przysłówkowe współczesne cechują się wysoką frekwencją we wszystkich odmianach języka i co więcej, użycie form zakończonych na -ąc (w przeciwieństwie do form z końcówką -szy) staje się coraz bardziej popularne. K. Bojałkowska pisze z kolei:

\footnotetext{
Z moich obserwacji wynika, że formy imiesłowów współczesnych występują bardzo licznie nie tylko w tekstach pisanych, lecz także w języku mówionym, zarówno w odmianie bardziej starannej, jak i w języku potocznym. Szczególnie często [...] występują w relacjach sportowych, w kronikach kryminalnych zamieszczanych w gazetach codziennych, w języku reklam, $[\ldots] \mathrm{w}$ tekstach legislacyjnych.
} 
Imiesłowy przysłówkowe współczesne miałyby zatem - zdaniem badaczek - charakteryzować także odmianę mówioną języka polskiego. K. Bojałkowska (2010: 20-21) przejrzała zasoby korpusu IPI PAN w celu zbadania proporcji pomiędzy liczbą wystąpień imiesłowów uprzednich i współczesnych w poszczególnych rejestrach języka. Zauważyła, że najwięcej form -szy w stosunku do - ac występuje w tekstach naukowo-dydaktycznych (stosunek $1: 11,5$ ); w beletrystyce jest to stosunek $1: 19$, zaś średnia dla wszystkich stylów wynosi $1: 35$. Taka proporcja utrzymuje się w tekstach napisanych po drugiej wojnie światowej i współczesnych. W materiałach z pierwszej połowy XX w. wynosi ona $1: 5,36$, a więc asymetria występowania obu participiów była wówczas znacznie mniejsza.

Zanikanie form na -szy i powiększającą się dysproporcję w użyciu obu typów imiesłowów przysłówkowych zaobserwowali także inni językoznawcy. Maciej Eder, Rafał L. Górski i Magdalena Król (2019) wykazali metodami korpusowymi, że natężenie występowania imiesłowów przysłówkowych uprzednich osiągnęło swój szczyt w XVII w., po czym zaczęło stopniowo maleć.

Barbara Bartnicka (1970: 167) pisze, że w języku polskim zaszła na przestrzeni dziejów redukcja zasobu imiesłowów przymiotnikowych, dlatego że zatarły się opozycje wyrażające stosunki czasowe. Pozostała jedynie opozycja strony: ,[...] selekcja typów imiesłowów doprowadziła do zachowania tylko jednej pary opozycyjnej pod względem strony". Niewykluczone, że można odnieść tę uwagę także do obecnego zanikania imiesłowu przysłówkowego uprzedniego. Niektórzy badacze przypuszczają (Buttler, Kurkowska, Satkiewicz 1986: 419), że oba imiesłowy przysłówkowe scalą się w przyszłości w jeden uogólniony imiesłów na -acc.

Katarzyna Burska w książce poświęconej analityzmom ${ }^{3}$ w języku prasowym (2016: 40) twierdzi za Stanisławem Szoberem (1959), że niektóre konstrukcje z imiesłowami to analityzmy czasownikowe, które odbiegają znaczeniem od syntetycznych form czasowników, gdyż, jej zdaniem, „pozwalają wyrazić właściwości ujmowane poza kategorią czasu, np. było pachnące vs. pachniało". W dalszej części pracy autorka pokazuje, że imiesłowy przymiotnikowe mogą wchodzić w zakres prawie wszystkich typów analityzmów, które z kolei charakteryzują styl prasowy (publicystyczny). Na S. Szobera powołują się także Danuta Buttler, Halina Kurkowska i Halina Satkiewicz (1987: 57-69), gdy omawiają to samo zjawisko multiwerbizacji. Dla tego pierwszego było ono przejawem przedmiotowego ujmowania świata, znamiennego dla współczesnego człowieka, podczas gdy wspomniane badaczki widzą w nim przede wszystkim konkretną potrzebę komunikacyjną - potrzebę ścisłości przekazu. Postrzegają analityzmy jako typowe nie tylko dla stylu publicystycznego, ale ogólniej: dla języka pisanego, a w szczególności dla jego wybitnie ceniących precyzję odmian, tj. stylu naukowego i urzędowego.

Jeśli chodzi o quasi-imiesłowy, Marzena Stępień (2017) wyróżnia około sześćdziesięciu takich konstrukcji. Badaniem ich zajmowali się także m.in.: Irena Bellert (1977), Wolfgang Niehüser (1987), Andrzej Moroz (2007), Marzena Stępień (2014), Sandra Birzer (2012, 2015, 2016), Emilia Kubicka (2017, 2018); piszą o nich także m.in. H. Wróbel (1975: 91) i K. Bojałkowska (2010: 19-20). Andrzej Bogusławski $(1978,1988)$ pisze,

${ }^{3}$ Analityzmy (multiwerbizmy) to konstrukcje wielowyrazowe, które mają jednowyrazowe odpowiedniki. 
że imiesłowy przysłówkowe stanowią podstawę operacji semantycznej, której efektem są quasi-imiesłowowe wyrażenia parentetyczne; z kolei Jadwiga Wajszczuk (1997, 2005) zwraca uwagę na metatekstową i metapredykatywną funkcję quasi-imiesłowów. Niezależnie od sposobu ujęcia zagadnienia, zasada tożsamości podmiotu i względnej relacji czasowej w przypadku quasi-imiesłowów nie obowiązuje, ponieważ odnoszą się one do sposobu, w jaki autor wypowiedzenia formułuje swą myśl, a nie bezpośrednio do opisywanych przez niego czynności i ich wykonawców. Spójrzmy na przykładowe zdanie: Szczerze mówiąc, biegacze byli bardzo zmęczeni. Jeśli zrozumiemy je w sposób zgodny z powszechnym uzusem, to będzie dla nas jasne, że to nie biegacze, lecz autor wypowiedzi pozwala sobie na szczerość.

\section{Dystrybucja imiesłowów i quasi-imiesłowów}

Pierwsze dwa przeprowadzone przez mnie badania posłużyły do opisu dystrybucji imiesłowów i quasi-imiesłowów w różnych stylach funkcjonalnych języka.

\subsection{Metoda badawcza}

Występowanie imiesłowu przysłówkowego uprzedniego, przysłówkowego współczesnego, przymiotnikowego czynnego i przymiotnikowego biernego dla wszystkich typów funkcjonalnych wyróżnionych w Narodowym Korpusie Języka Polskiego przebadałam niezależnie na danych zaczerpniętych z tegoż korpusu. Dane o dystrybucji imiesłowów i quasi-imiesłowów w stylach pobrałam z wersji zrównoważonej trzystumilionowej; jedynie w przypadku objętościowo niewielkiego stylu mówionego medialnego, nieuwzględnionego w korpusie zrównoważonym, korzystałam z pełnego korpusu.

Typów funkcjonalnych wyróżniono w korpusie piętnaście i są to:

- typ publicystyczny,

- typ internetowy interaktywny (np. fora, blogi z komentarzami, listy dyskusyjne),

- typ internetowy nieinteraktywny (np. strony domowe, blogi bez komentarzy),

- typ naukowo-dydaktyczny,

- typ informacyjno-poradnikowy,

- typ urzędowy,

- typ quasi-mówiony (np. stenogramy z obrad Sejmu),

- typ mówiony medialny (np. zapisy audycji radiowych),

- typ mówiony konwersacyjny (nagrania autentycznych rozmów prywatnych),

- literatura,

- literatura faktu,

- poezja,

- dramat,

- proza,

- inne (np. ulotki, rękopisy, druki ogłoszeniowe).

${ }^{4}$ Zapisy wypowiedzi w Sejmie i Senacie są poddawane pewnej obróbce redakcyjnej i dlatego nie mogą być traktowane jako w pełni wiarygodny zapis polszczyzny mówionej. 
Korpus nie zawsze rozróżnia poezję, prozę i dramat; oprócz podziału szczegółowego wprowadzono jeden zbiorczy typ literacki, obejmujący całą literaturę piękną. Ja posłużyłam się tylko kategorią zbiorczą, dzieląc ją z kolei na literaturę piękną przed 1950 r. i literaturę piękną od 1950 r. Postąpiłam tak w związku ze wzmiankowaną wyżej tezą o zanikaniu imiesłowów uprzednich. Nie wprowadzałam jednak rozróżnienia czasowego dla pozostałych typów funkcjonalnych, dlatego iż korpus składa się prawie całkowicie z tekstów powstałych w drugiej połowie XX w. i później, a literatura piękna stanowi tutaj wyjątek od reguły.

Wszystkie tabele i wykresy w tym artykule zawierają dane znormalizowane. Poszczególne liczby wystąpień przedstawiam w przeliczeniu na 10000 słów dla każdego stylu osobno. Neutralizuję w ten sposób różnice w objętości zbiorów pochodzących z różnych kanałów tekstowych, a same liczby stają się bardziej czytelne.

\begin{tabular}{|l|r|}
\hline \multicolumn{1}{|c|}{ Styl } & Liczba segmentów w korpusie \\
\hline Informacyjno-poradnikowy & 9966699 \\
\hline Internetowy interaktywny & 10997832 \\
\hline Internetowy nieinteraktywny & 4419120 \\
\hline Literatura faktu & 18333573 \\
\hline Literatura piękna do 1950 r. & 651092 \\
\hline Literatura piękna od 1950 r. & 542129 \\
\hline Mówiony konwersacyjny & 2003491 \\
\hline Mówiony medialny & 100755 \\
\hline Naukowo-dydaktyczny & 10889040 \\
\hline Publicystyczny & 153390194 \\
\hline Quasi-mówiony & 27868582 \\
\hline Inne & 2718391 \\
\hline
\end{tabular}

Tabela nr 1. Objętości analizowanych stylów w NKJP.

Pierwszym krokiem (Badanie 1) było zbadanie dystrybucji imiesłowów w stylach. Do tego celu posłużyłam się analizą korespondencji. Jest to metoda statystyczna, która pozwala uzyskać informacje o strukturze powiązań między kolumnami i wierszami tabeli wielodzielczej, a jej wykres umożliwia intuicyjne wnioskowanie o wzajemnych relacjach pomiędzy kategoriami zmiennych. Dobry opis tej techniki można znaleźć na przykład w pracy Michaela J. Greenacre’a (2010). W przypadku Badania 1 oznacza to, że jeśli dane dotyczące dystrybucji zostaną zapisane w postaci tabeli o czterech wierszach (imiesłowy) i trzynastu kolumnach (style), to każde trzynaście wartości w poszczególnych wierszach zostanie potraktowane jako punkty w układzie współrzędnych w przestrzeni trzynastowymiarowej. Odległości pomiędzy nimi zawierają informację o podobieństwie pomiędzy wierszami na tablicy. Wykres analizy korespondencji jest rzutem 
tego układu współrzędnych na płaszczyznę - przestrzeń trzynastowymiarowa zostaje zredukowana do przestrzeni dwuwymiarowej. W efekcie tracimy informację o częstościach bezwzględnych występowania imiesłowów w stylach, natomiast wykres pokazuje za pomocą odległości pomiędzy punktami relację każdej zmiennej w stosunku do wszystkich pozostałych jednocześnie.

Następnie (tj. w Badaniu 2) zbadałam frekwencję i dystrybucję quasi-imiesłowów. Opierając się na artykule M. Stępień (2017), przygotowałam listę quasi-imiesłowowych związków wyrazowych, po czym zredukowałam ją do związków występujących co najmniej 200 razy w NKJP i co do których nie miałam wątpliwości, że reguła tożsamości podmiotu rzeczywiście w ich wypadku nie obowiązuje. W niektórych wypadkach uszczegółowiłam listę z przyczyn natury technicznej, np. „(jakoś) mówiąc” rozpisałam na ,szczerze mówiąc”, „krótko mówiąc” itd. Ostatecznie zebrałam próbkę 38 form (zob. Lista 1); policzyłam ich wystąpienia w korpusie trzystumilionowym (a pełnym dla mówionego medialnego), po czym zsumowałam wyniki osobno dla quasi-imiesłowów przysłówkowych uprzednich i współczesnych. Wyniki zostały następnie znormalizowane. Dało to przybliżoną informację o skali zjawiska.

\begin{tabular}{|l|l|l|l|}
\hline (jakoś) rzecz biorąc & dokładniej mówiąc & nie pomijając & zważywszy (na/że) \\
\hline nawiązując (do) & ogólnie mówiąc & prawdę powiedziawszy & uwzględniając \\
\hline wracając (do) & kończąc (na) & mówiąc prościej & reasumując \\
\hline nie mówiąc już (o) & skończywszy (na) & (jakoś) rzecz ujmując & konkludując \\
\hline prawdę mówiąc & począwszy (od) & nie wspominając & podsumowując \\
\hline krótko mówiąc & poczynając (od) & nie wyłączając & wliczając \\
\hline szczerze mówiąc & abstrahując (od) & przyjmując (że) & włączając \\
\hline inaczej mówiąc & pamiętając (o) & zakładając (że) & wyjąwszy \\
\hline dokładnie mówiąc & sądząc (po) & założywszy (że) & \\
\hline ściśle mówiąc & biorąc (pod uwagę/rozwagę) & zważając (na/że) & \\
\hline
\end{tabular}

Lista 1. Frazeologizmy imiesłowowe (quasi-imiesłowy).

\subsection{Wyniki}

\subsubsection{Badanie 1: frekwencja imiesłowów w poszczególnych stylach}

Po znormalizowaniu liczby wystąpień na 10000 segmentów w każdym typie funkcjonalnym i policzeniu średniej dla całego korpusu odkryłam, że zdecydowanie najczęściej (trochę ponad 100 razy na 10000 słów, a więc więcej niż raz na 100 słów) Polacy posługują się imiesłowem przymiotnikowym biernym, następnie zaś - ponad

${ }^{5}$ Należy oczywiście pamiętać, że NKJP jest tylko pewną próbą odzwierciedlenia języka i stanowi przybliżenie, a nie dokładne odwzorowanie tego, jak w rzeczywistości rodzimi użytkownicy języka operują językiem polskim. 
dwa razy rzadziej - imiesłowem przymiotnikowym czynnym, a potem jeszcze ponad dwa razy rzadziej imiesłowem przysłówkowym współczesnym; natomiast imiesłów przysłówkowy uprzedni jest formą marginalną, gdyż występuje jedynie 0,69 razy na 10000 słów.

Stylem, w którym imiesłowy przymiotnikowe cieszą się największą popularnością, jest styl urzędowy, a zaraz po nim naukowo-dydaktyczny. Uwagę przykuwa typ quasi-mówiony (tj. styl przemówień z parlamentu) - można dostrzec, że imiesłowy przymiotnikowe są w nim dużo powszechniejsze niż w pozostałych typach mówionych. W sposób najbardziej do niego zbliżony prezentuje się typ informacyjno-poradnikowy.

Przykład 1: Użycie imiesłowów przymiotnikowych w stylu urzędowym.

Art. 69 . § 1. Protokół przesłuchania powinien być odczytany i przedstawiony do podpisu osobie zeznającej niezwłocznie po złożeniu zeznania.

(Kodeks postępowania administracyjnego, 1960 r., źródło: NKJP)

\begin{tabular}{|l|c|c|c|c|}
\hline \multicolumn{1}{|c|}{ Typ } & Im. bierny & Im. czynny & $\begin{array}{c}\text { Im. } \\
\text { wspólczesny }\end{array}$ & Im. uprzedni \\
\hline Informacyjno-poradnikowy & 132,30 & 47,31 & 25,28 & 0,63 \\
\hline Internetowy interaktywny & 50,68 & 14,05 & 11,43 & 0,34 \\
\hline Internetowy nieinteraktywny & 116,02 & 35,16 & 17,60 & 0,36 \\
\hline Literatura faktu & 99,98 & 39,64 & 30,08 & 2,47 \\
\hline Literatura piękna do 1950 r. & 103,64 & 38,17 & 47,37 & 7,71 \\
\hline Literatura piękna od 1950 r. & 79,58 & 34,62 & 43,61 & 2,29 \\
\hline Mówiony konwersacyjny & 33,16 & 2,64 & 3,03 & 0,13 \\
\hline Mówiony medialny & 83,17 & 16,48 & 14,89 & 0,40 \\
\hline Naukowo-dydaktyczny & 163,39 & 71,78 & 23,49 & 0,72 \\
\hline Publicystyczny & 103,27 & 38,77 & 17,06 & 0,52 \\
\hline Quasi-mówiony & 131,95 & 47,14 & 17,55 & 0,40 \\
\hline Urzędowy & 208,94 & 92,43 & 22,83 & 0,61 \\
\hline Inne & 103,78 & 47,40 & 34,12 & 2,26 \\
\hline Średnia dla całego korpusu & 111,05 & 42,08 & 18,85 & 0,69 \\
\hline
\end{tabular}

Tabela nr 2. Frekwencja imiesłowów w stylach (na 10000 słów).

Użycia imiesłowów przysłówkowych są z kolei charakterystyczne przede wszystkim dla literatury pięknej. Zdecydowanie wyróżniają się tutaj imiesłowy uprzednie, które właściwie tylko w literaturze (oraz w enigmatycznej kategorii „inne”) są wyraźnie dostrzegalne. 
Przykład 2: Użycie imiesłowu przysłówkowego uprzedniego we współczesnym tekście literackim.

Ładne, regularne wgłębienia, ślady jej krótkich, ostrożnych kroków wypełniały się wodą, ale ich kontur pozostał widoczny nawet wtedy, gdy skręciwszy w stronę miasta, znikła za najbliższym nawisem stromego brzegu.

(Mirosław M. Bujko, Wyspy szerszenia, 2008 r., źródło: NKJP)

Rzeczywiście, liczba imiesłowów uprzednich drastycznie spadła po 1950 r.; warto zwrócić przy tym uwagę, że po 1950 r. nastąpił spadek liczby wszystkich imiesłowów. Co prawda, w przypadku imiesłowu przysłówkowego współczesnego i imiesłowu przymiotnikowego czynnego spadek ten jest raczej niewielki (odpowiednio o $8 \%$ i $9 \%$ ), dla imiesłowu przymiotnikowego biernego umiarkowany (o 23\%), a w przypadku imiesłowu uprzedniego - ogromny (o 70\%). Niemniej dane te nie potwierdzają formułowanej przez niektórych badaczy tezy o wzrastającej liczbie imiesłowów współczesnych, choć trzeba w tym miejscu przypomnieć, że NKJP nie dostarcza nam informacji diachronicznych dla stylów innych niż literatura piękna. Niewykluczone więc, że liczba ich wzrosła w polszczyźnie mówionej i tekstach użytkowych, a nieznacznie zmalała jedynie w literaturze; taki rozwój jest jednak niezgodny z intuicją.

Ciekawych danych dostarcza analiza korespondencji, zobrazowana na rysunku nr 1.

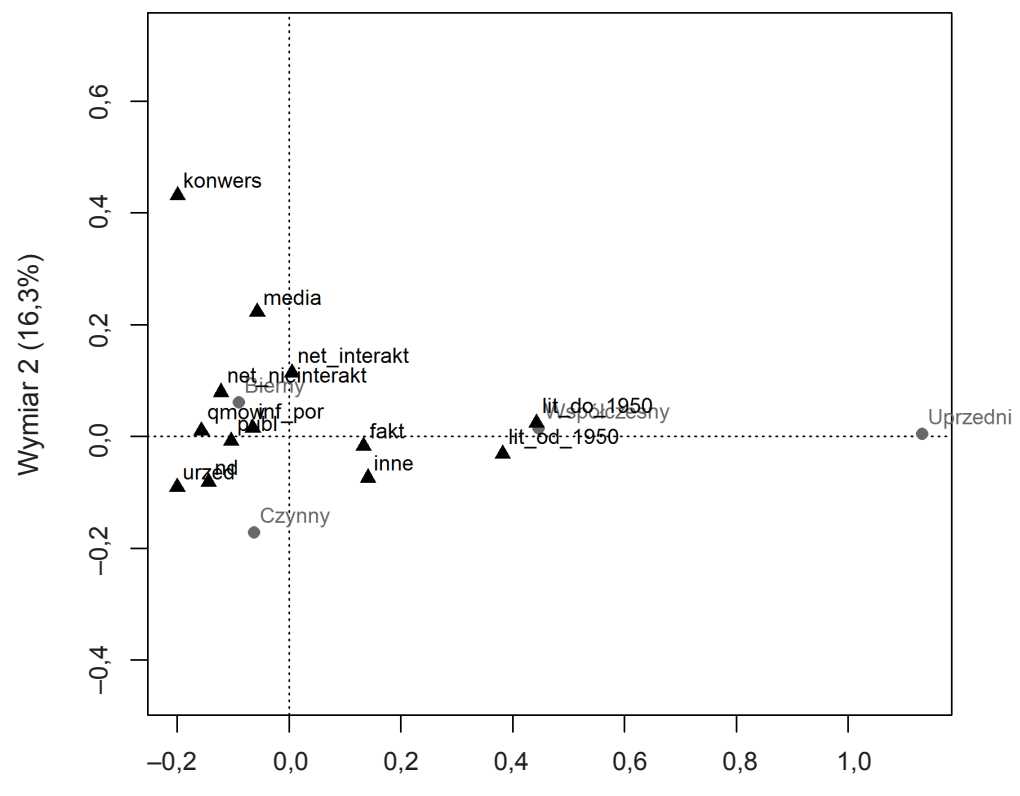

Wymiar $1(77,3 \%)$

Rysunek nr 1. Wykres analizy korespondencji dla czterech typów imiesłowów w NKJP. 
Widać na wykresie po odległościach pomiędzy punktami, że imiesłów przysłówkowy uprzedni zdecydowanie odstaje od pozostałych imiesłowów. Plasuje się bliżej literatury pięknej niż innych stylów. Podobnie zachowuje się imiesłów przysłówkowy współczesny, który jednakże nie jest już tak odległy od stylów użytkowych. Z tekstami użytkowymi wyraźnie zgrupowały się imiesłowy przymiotnikowe. Imiesłów przymiotnikowy czynny występuje w najbliższym sąsiedztwie tekstów urzędowych i naukowo-dydaktycznych; bierny obecny jest w bardzo wielu różnych stylach.

Wykres ten mówi sporo o samych typach funkcjonalnych. W osi pionowej zauważyć można gradację formalności rejestrów językowych, natomiast w osi poziomej ujawnia się podział na typy informacyjne i fikcjonalne, z literaturą faktu umiejscowioną pomiędzy nimi. Styl quasi-mówiony wyraźnie odróżnia się od innych stylów mówionych, plasując się znacznie bliżej języka publicystycznego niż mówionego medialnego.

\subsubsection{Badanie 2: frekwencja quasi-imiesłowów}

Dane frekwencyjne dla frazeologizmów imiesłowowych wnoszą nowe, ciekawe informacje. Rysunki nr 2 i 3 przedstawiają porównanie częstości występowania imiesłowów i quasi-imiesłowów.

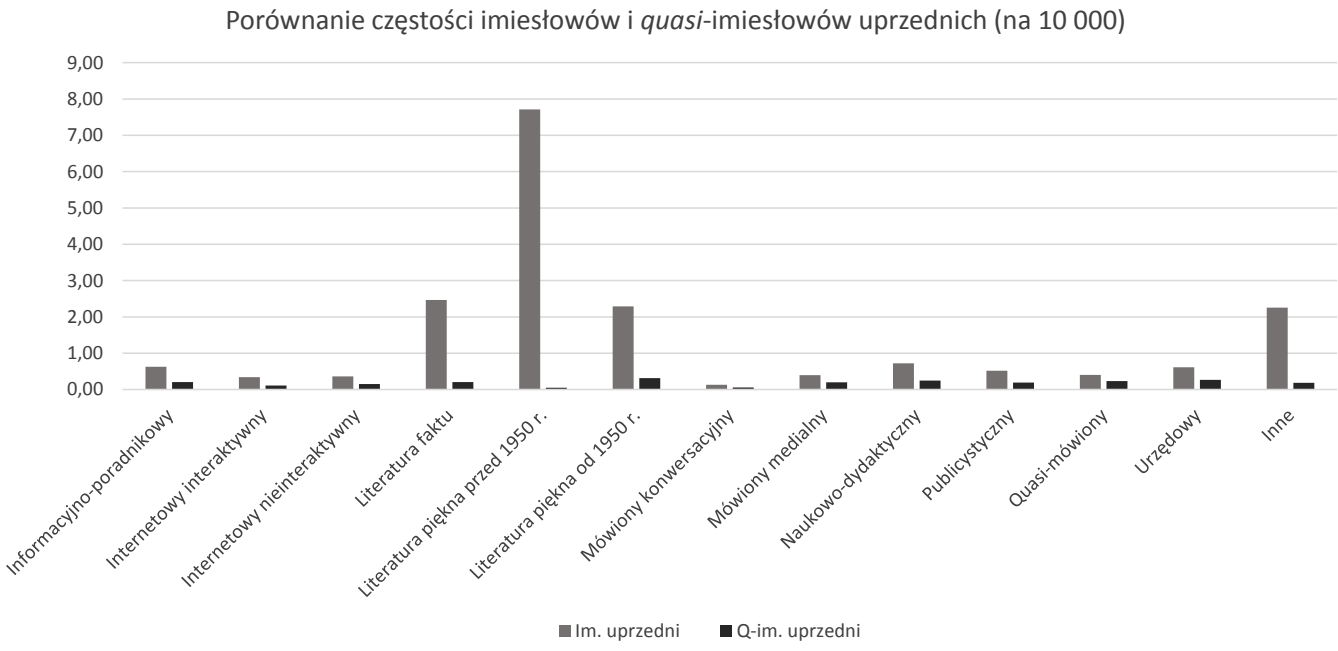

Rysunek nr 2. Porównanie częstości imiesłowów i quasi-imiesłowów uprzednich (na 10000 słów).

To, co można wydedukować z obu wykresów, gdy porówna się ze sobą wysokości słupków połączonych w pary, zostało przedstawione za pomocą procentów w tabeli nr 3 . 
O ile quasi-imiesłowy współczesne stanowią zauważalny procent użyć odpowiadających im participiów jedynie w przypadku stylu mówionego konwersacyjnego (21\%), urzędowego (11\%) i internetowego interaktywnego (9\%), o tyle quasi-imiesłowy uprzednie wywierają znaczący wpływ na frekwencję imiesłowów przysłówkowych uprzednich praktycznie w każdym przypadku poza literaturą piękną przed $1950 \mathrm{r}$.

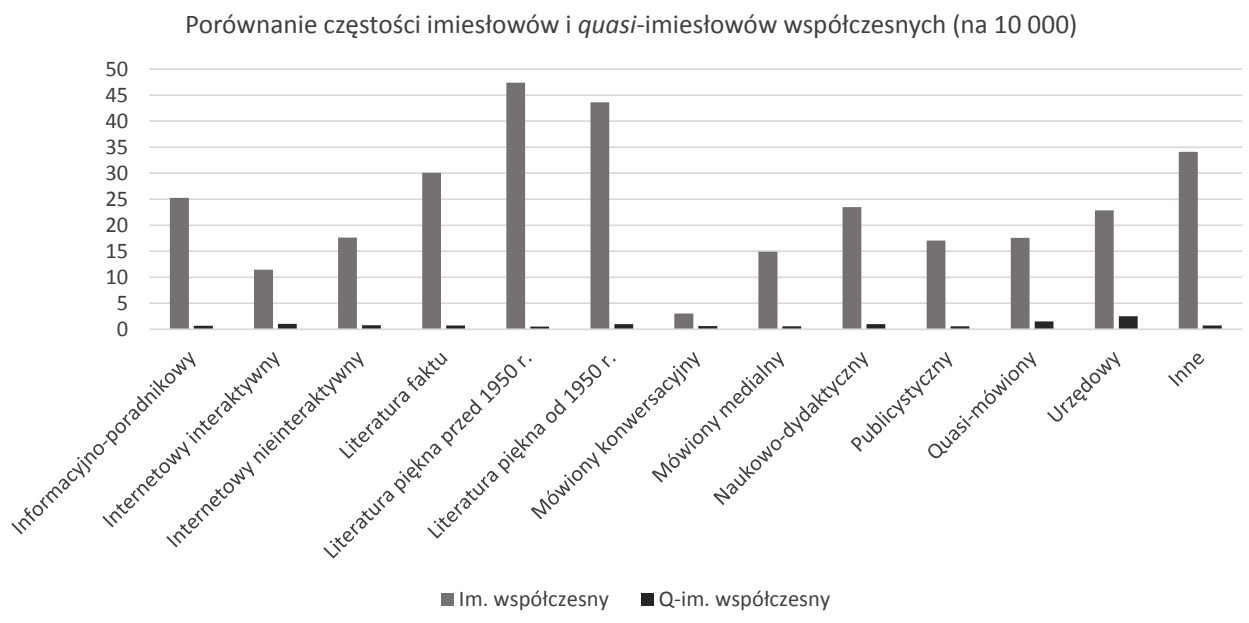

Rysunek nr 3: Porównanie częstości imiesłowów i quasi-imiesłowów współczesnych (na 10000 słów).

\begin{tabular}{|l|c|c|}
\hline \multicolumn{1}{|c|}{ Typy } & Uprzednie & Współczesne \\
\hline Informacyjno-poradnikowy & $33 \%$ & $3 \%$ \\
\hline Internetowy interaktywny & $32 \%$ & $9 \%$ \\
\hline Internetowy nieinteraktywny & $41 \%$ & $5 \%$ \\
\hline Literatura faktu & $8 \%$ & $2 \%$ \\
\hline Literatura piękna przed 1950 r. & $1 \%$ & $1 \%$ \\
\hline Literatura piękna od 1950 r. & $14 \%$ & $2 \%$ \\
\hline Mówiony konwersacyjny & $42 \%$ & $21 \%$ \\
\hline Mówiony medialny & $50 \%$ & $4 \%$ \\
\hline Naukowo-dydaktyczny & $34 \%$ & $4 \%$ \\
\hline Publicystyczny & $37 \%$ & $3 \%$ \\
\hline Quasi-mówiony & $58 \%$ & $9 \%$ \\
\hline Urzędowy & $43 \%$ & $11 \%$ \\
\hline Inne & $8 \%$ & $2 \%$ \\
\hline
\end{tabular}

Tabela nr 3. Procent quasi-imiesłowów wśród form oznaczonych w NKJP jako imiesłowy przysłówkowe. 
Jest to kolejny argument przemawiający za tym, że imiesłowy uprzednie zanikają we współczesnej polszczyźnie. Co ciekawe, spośród 38 wyszczególnionych quasi-imiesłowów jedynie 6 to quasi-imiesłowy uprzednie, a jednak ich udział procentowy $\mathrm{w}$ odpowiadającym im materiale korpusowym, analizowanym w Badaniu 1, okazał się dużo większy niż udział quasi-imiesłowów współczesnych. Obrazuje to, jak rzadkie $\mathrm{w}$ istocie są imiesłowy uprzednie (por. tabela $\mathrm{nr} 4$ ).

\begin{tabular}{|l|c|c|c|c|c|c|}
\hline \multicolumn{1}{|c|}{ Typ } & $\begin{array}{c}\text { skoń- } \\
\text { czywszy } \\
\text { na }\end{array}$ & $\begin{array}{c}\text { począwszy } \\
\text { od }\end{array}$ & $\begin{array}{c}\text { prawdę } \\
\text { powie- } \\
\text { dziawszy }\end{array}$ & $\begin{array}{c}\text { zało- } \\
\text { żywszy, } \\
\text { że }\end{array}$ & $\begin{array}{c}\text { zwa- } \\
\text { żywszy }\end{array}$ & wyjąwszy \\
\hline $\begin{array}{l}\text { Informacyjno- } \\
\text { poradnikowy }\end{array}$ & 0,030 & 0,154 & 0,003 & 0,000 & 0,018 & 0,002 \\
\hline $\begin{array}{l}\text { Internetowy } \\
\text { interaktywny }\end{array}$ & 0,016 & 0,045 & 0,009 & 0,000 & 0,036 & 0,003 \\
\hline $\begin{array}{l}\text { Internetowy } \\
\text { nieinteraktywny }\end{array}$ & 0,007 & 0,070 & 0,000 & 0,000 & 0,066 & 0,007 \\
\hline Literatura faktu & 0,014 & 0,077 & 0,012 & 0,002 & 0,079 & 0,020 \\
\hline $\begin{array}{l}\text { Literatura piękna } \\
\text { przed 1950 r. }\end{array}$ & 0,015 & 0,031 & 0,000 & 0,000 & 0,000 & 0,000 \\
\hline $\begin{array}{l}\text { Literatura piękna } \\
\text { od 1950 r. }\end{array}$ & 0,000 & 0,074 & 0,221 & 0,000 & 0,000 & 0,018 \\
\hline $\begin{array}{l}\text { Mówiony } \\
\text { konwersacyjny }\end{array}$ & 0,005 & 0,010 & 0,030 & 0,000 & 0,010 & 0,000 \\
\hline $\begin{array}{l}\text { Mówiony } \\
\text { medialny }\end{array}$ & 0,099 & 0,099 & 0,000 & 0,000 & 0,000 & 0,000 \\
\hline $\begin{array}{l}\text { Naukowo- } \\
\text {-dydaktyczny }\end{array}$ & 0,018 & 0,178 & 0,005 & 0,000 & 0,038 & 0,006 \\
\hline Publicystyczny & 0,019 & 0,107 & 0,004 & 0,000 & 0,055 & 0,007 \\
\hline Quasi-mówiony & 0,013 & 0,116 & 0,014 & 0,000 & 0,089 & 0,001 \\
\hline Urzędowy & 0,000 & 0,143 & 0,000 & 0,000 & 0,113 & 0,009 \\
\hline Inne & 0,004 & 0,096 & 0,000 & 0,004 & 0,070 & 0,015 \\
\hline
\end{tabular}

Tabela nr 4. Frekwencja quasi-imiesłowów uprzednich w przełożeniu na 10000 wystąpień.

\section{Badania 3 i 4: zależność od długości zdania}

Celem dalszych dwóch badań była odpowiedź na pytanie o przyczyny takiej, a nie innej dystrybucji imiesłowów w różnych stylach funkcjonalnych. Wyszłam z założenia, że może istnieć zależność pomiędzy długością zdania a częstością występowania imiesłowów. 


\subsection{Metoda badawcza}

Badanie 3 dotyczyło zatem kwestii, czy rzeczywiście częstość występowania imiesłowów wzrasta wraz z długością zdania. Posłużyłam się tutaj milionowym NKJP, do którego jest dostępna do pobrania wersja źródłowa (można dzięki temu przebadać materiał na głębszym poziomie). Nie uwzględniałam w tym kroku podziału na style. Wydobyłam natomiast $\mathrm{z}$ korpusu milionowego informacje o długości wszystkich zdań w korpusie z osobna, a także o liczbie występujących w nich imiesłowów.

Policzyłam, czy prawdopodobieństwo, iż przypadkowe słowo będzie imiesłowem, rośnie, gdy zdania stają się dłuższe. Materiał składający się ze wszystkich zdań w milionowym korpusie (bez podziału na typy funkcjonalne) pogrupowałam na zdania o zbliżonej długości. Wyróżniłam dziesięć różnych grup, tzn. dziesięć przedziałów długości zdania. Najkrótszy przedział zawierał wszystkie zdania o długości od 1 do 4 segmentów, najdłuższy zaś zdania o długości od 45 do 49 segmentów. Zdania dłuższe niż 49 segmentów nie były brane pod uwagę. Następnie obliczyłam sumę wszystkich słów w każdym przedziale oraz sumy wszystkich znajdujących się tam imiesłowów (każdy rodzaj imiesłowu był traktowany oddzielnie). Prawdopodobieństwo, że przypadkowe słowo będzie imiesłowem, policzyłam według powszechnie znanego wzoru:

$$
P(A)=\frac{|A|}{|\Omega|}
$$

P(A) oznacza prawdopodobieństwo trafienia, że dane słowo będzie imiesłowem konkretnego typu; $|\mathrm{A}|$ oznacza liczbę wszystkich takich imiesłowów w przedziale, a $|\Omega|$ oznacza liczbę wszystkich słów (segmentów) w przedziale.

Podobne obliczenia przeprowadziłam dla czterech innych typów form (tj. czasownika finitywnego teraźniejszego/przyszłego, gerundium, przymiotnika i liczebnika), ale wyniki omówię bardzo skrótowo - chodziło jedynie o szybkie wykluczenie, że zaobserwowana prawidłowość zachodzi dla dowolnej formy gramatycznej. Materiał z milionowego korpusu jest za mały, by dzielić każdy z przedziałów jeszcze dodatkowo na kolejne 12 części, tj. obliczać prawdopodobieństwa przy rosnącej długości zdania dla każdego typu funkcjonalnego z osobna.

Badanie 4 polegało z kolei na porównaniu średniej długości zdania i frekwencji imiesłowów dla każdego stylu. Średnią długość zdania dla każdego ze stylów obliczyłam na podstawie danych zawartych w korpusie milionowym. Uwzględniłam podział na typy funkcjonalne, natomiast nie wprowadzałam już rozróżnienia na literaturę piękną przed rokiem 1950 i późniejszą. Następnie zestawiłam ze sobą dane frekwencyjne z Badań 1 i 2 (po odjęciu liczby quasi-imiesłowów) i średnią długość zdania w stylach. Korpus milionowy jest wiernym pomniejszeniem wersji trzystumilionowej pod względem anotacji i ogólnej konstrukcji, zatem dane pozyskane z wersji milionowej można porównać z zaczerpniętymi na użytek Badań 1 i 2 danymi frekwencyjnymi z obszerniejszej wersji NKJP. 
Wyrysowałam wykresy dla każdego rodzaju imiesłowu z osobna, by sprawdzić, czy przypominają one w przybliżeniu wykresy funkcji liniowej, a następnie obliczyłam dla nich współczynnik korelacji Pearsona, który służy do ustalania stopnia zależności liniowej pomiędzy dwiema zmiennymi. Jest on ilorazem kowariancji oraz iloczynu odchyleń standardowych tych zmiennych. Wartości współczynnika mieszczą się w przedziale od (-1) do 1 . Wartości powyżej 0,5 wskazują na mocną korelację dodatnią, a poniżej $(-0,5)$ na mocną korelację ujemną. Wartości bliskie 0 wskazują na brak korelacji liniowej.

\subsection{Wyniki}

4.2.1. Badanie 3: rosnąca długość zdania a częstość imiesłowu na podstawie korpusu milionowego

Badanie 3 polegało na obliczeniu, czy prawdopodobieństwo, iż słowo w zdaniu będzie imiesłowem, rzeczywiście rośnie wraz ze wzrastającą długością zdania. Poniżej prezentuję tabelę z danymi oraz utworzone na jej podstawie wykresy prawdopodobieństwa trafienia na każdy z czterech imiesłowów w zależności od długości zdania.

\begin{tabular}{|c|c|c|c|c|c|}
\hline $\begin{array}{c}\text { Długość zdania } \\
\text { w segmentach }\end{array}$ & Uprzedni & Czynny & Współczesny & Bierny & $\begin{array}{c}\text { Liczba } \\
\text { segmentów } \\
\text { w tym } \\
\text { przedziale }\end{array}$ \\
\hline $1-4$ & 0 & 39 & 4 & 162 & 29358 \\
\hline $5-9$ & 13 & 347 & 146 & 1586 & 169634 \\
\hline $10-14$ & 21 & 931 & 414 & 2954 & 231812 \\
\hline $15-19$ & 38 & 1151 & 528 & 3252 & 223037 \\
\hline $20-24$ & 20 & 1136 & 420 & 2845 & 182222 \\
\hline $25-29$ & 15 & 911 & 355 & 2071 & 128520 \\
\hline $30-34$ & 17 & 640 & 247 & 1385 & 86203 \\
\hline $35-39$ & 10 & 437 & 189 & 978 & 58439 \\
\hline $40-44$ & 10 & 275 & 115 & 648 & 36401 \\
\hline $45-49$ & 7 & 198 & 74 & 408 & 23325 \\
\hline 50 i więcej & 5 & 450 & 124 & 845 & 46562 \\
\hline
\end{tabular}

Tabela nr 5. Liczba imiesłowów a liczba wszystkich słów dla zdań o różnej długości.

Imiesłowy przysłówkowe uprzednie pojawiają się w materiale na tyle rzadko, że trudno niestety na podstawie różnic w liczbie wystąpień wyciągać twarde wnioski. Wyniki dla pozostałych trzech typów imiesłowów zdają się bardziej wiarygodne. 
Prawdopodobieństwo trafienia na imiesłów

(w wartościach bezwzględnych)

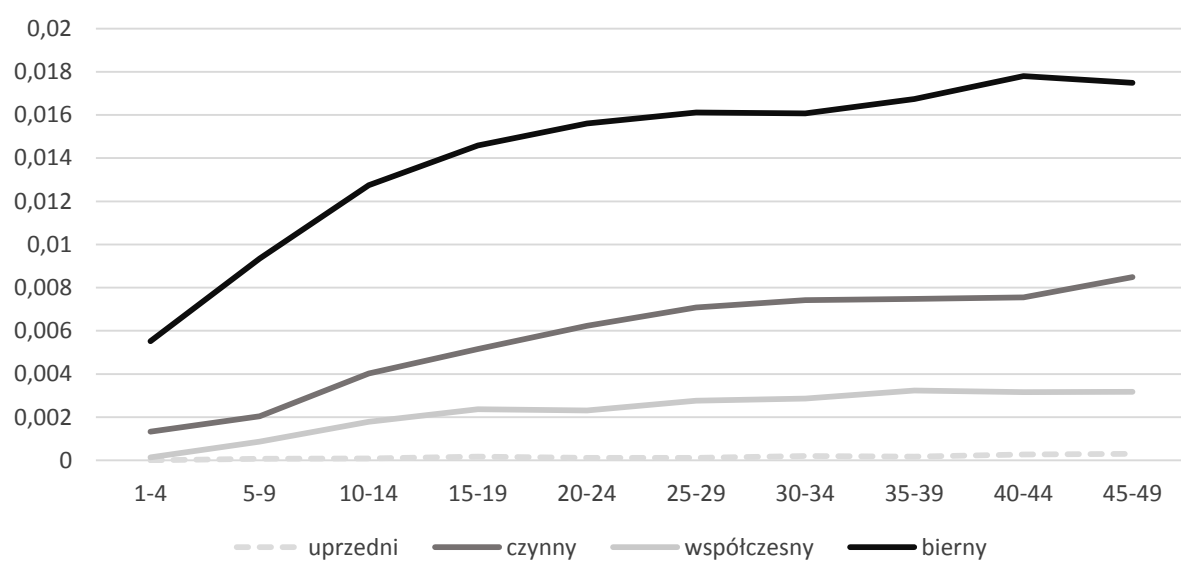

Rysunek nr 4. Prawdopodobieństwo trafienia na imiesłów (w wartościach bezwzględnych).

Prawdopodobieństwo trafienia na imiesłów (przeskalowanie wg wartości ostatniego argumentu)

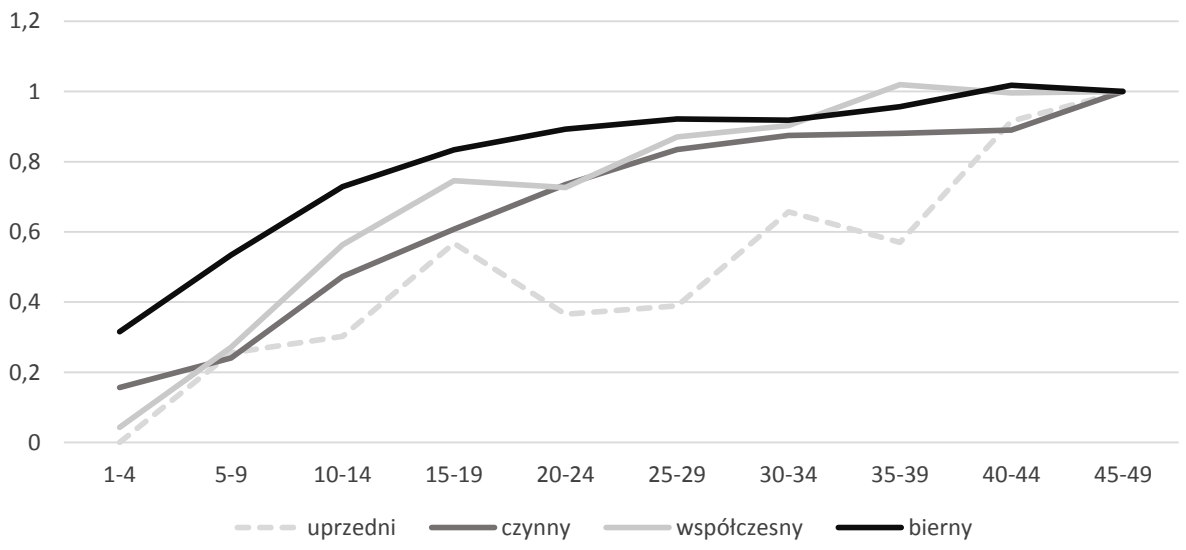

Rysunek nr 5. Prawdopodobieństwo trafienia na imiesłów (przeskalowane).

Rysunek nr 5 pokazuje kształty krzywych tak, jak wyglądają one na wykresach utworzonych osobno dla każdego typu imiesłowu. Rysunek nr 4, na którym zaprezentowano wyniki bez przeskalowania, może kreować błędne wrażenie, że prawdopodobieństwo trafienia na imiesłów nieszczególnie wzrasta w przypadku imiesłowów przysłówkowych. 
W rzeczywistości spłaszczenie tych krzywych wynika z zastosowania wspólnej skali do wartości różniących się rzędem wielkości. Przeskalowanie według wartości ostatniego argumentu (który uzyskuje na rysunku nr 5 wartość 1, a wszystkie pozostałe wartości są ujmowane jako jego odsetki) obrazuje rzeczywiste tempo przyrostu prawdopodobieństwa dla każdego typu imiesłowu z osobna.

Powyższe krzywe pokazują wyraźnie, że ogólna tendencja jest rosnąca - im dłuższe zdanie, tym większe prawdopodobieństwo trafienia na imiesłów. Porównawcza analiza dla czterech innych form: przymiotnika, liczebnika, czasownika finitywnego (teraźniejszego i przyszłego) oraz gerundium, wykazały, że każdy typ formy zachowuje się ,po swojemu” - prawdopodobieństwo trafienia na czasownik finitywny maleje wraz z długością zdania, gerundium zachowuje się zaś podobnie do imiesłowów. Dla przymiotników i liczebników prawdopodobieństwo wpierw gwałtownie przyrasta, by szybko osiągnąć stały pułap i pozostawać na mniej więcej tym samym poziomie (choć krzywa przymiotników dalej rośnie, tyle że minimalnie). Zatem to, co obserwujemy na wykresach 4 i 5, to właściwość akurat imiesłowów, a nie wszystkich form.

4.2.2. Badanie 4: korelacja pomiędzy frekwencją imiesłowów a średnią długością zdania w stylach

Wyniki Badania 3 pokazują, że zachodzi ogólna zależność pomiędzy długością zdania a częstością występowania imiesłowów. Pytanie brzmi, czy ta zależność może być czynnikiem determinującym dystrybucję imiesłowów w stylach. Należało zatem zbadać, czy istnieje korelacja pomiędzy średnią długością zdania w stylach a częstością występowania w nich imiesłowów. Poniżej prezentuję tabelę i wykresy z wynikami oraz wartości współczynnika Pearsona dla każdego z czterech typów imiesłowu.

\begin{tabular}{|l|c|c|c|c|c|}
\hline \multicolumn{1}{|c|}{ Typ } & $\begin{array}{c}\text { Przymiot- } \\
\text { nikowy } \\
\text { bierny }\end{array}$ & $\begin{array}{c}\text { Przymiot- } \\
\text { nikowy } \\
\text { czynny }\end{array}$ & $\begin{array}{c}\text { Przy- } \\
\text { słówkowy } \\
\text { współczesny }\end{array}$ & $\begin{array}{c}\text { Przy- } \\
\text { słówkowy } \\
\text { uprzedni }\end{array}$ & $\begin{array}{c}\text { Średnia } \\
\text { długość } \\
\text { zdania }\end{array}$ \\
\hline $\begin{array}{l}\text { Informacyjno- } \\
\text {-poradnikowy }\end{array}$ & 132,3 & 47,3 & 24,6 & 0,4 & 15,7 \\
\hline $\begin{array}{l}\text { Internetowy } \\
\text { interaktywny }\end{array}$ & 50,7 & 14,1 & 10,4 & 0,2 & 14,5 \\
\hline $\begin{array}{l}\text { Internetowy } \\
\text { nieinteraktywny }\end{array}$ & 116,0 & 35,2 & 16,8 & 0,2 & 16,0 \\
\hline Literatura faktu & 100,0 & 39,6 & 29,4 & 2,3 & 15,7 \\
\hline Literatura piękna & 92,7 & 36,6 & 44,9 & 5,1 & 11,9 \\
\hline $\begin{array}{l}\text { Mówiony } \\
\text { konwersacyjny }\end{array}$ & 33,2 & 2,6 & 2,4 & 0,1 & 8,0 \\
\hline Mówiony medialny & 83,2 & 16,5 & 14,3 & 0,2 & 9,8 \\
\hline $\begin{array}{l}\text { Naukowo- } \\
\text {-dydaktyczny }\end{array}$ & 163,4 & 71,8 & 22,5 & 0,5 & 20,4 \\
\hline
\end{tabular}




\begin{tabular}{|l|c|c|c|c|c|}
\hline Publicystyczny & 103,3 & 38,8 & 16,5 & 0,3 & 15,8 \\
\hline Quasi-mówiony & 132,0 & 47,1 & 16,0 & 0,2 & 13,3 \\
\hline Urzędowy & 208,9 & 92,4 & 20,3 & 0,3 & 26,7 \\
\hline Inne & 103,8 & 47,4 & 33,4 & 2,1 & 16,9 \\
\hline
\end{tabular}

Tabela nr 6. Porównanie liczby wystąpień imiesłowów na 10000 i średniej długości zdania.

Współczynnik korelacji Pearsona wyniósł odpowiednio:

Dla imiesłowu przymiotnikowego biernego: $\quad \mathrm{r} \approx 0,86$

Dla imiesłowu przymiotnikowego czynnego: $\quad \mathrm{r} \approx 0,91$

Dla imiesłowu przysłówkowego współczesnego: $\mathrm{r} \approx 0,22$

Dla imiesłowu przysłówkowego uprzedniego: $\quad \mathrm{r} \approx(-0,12)$
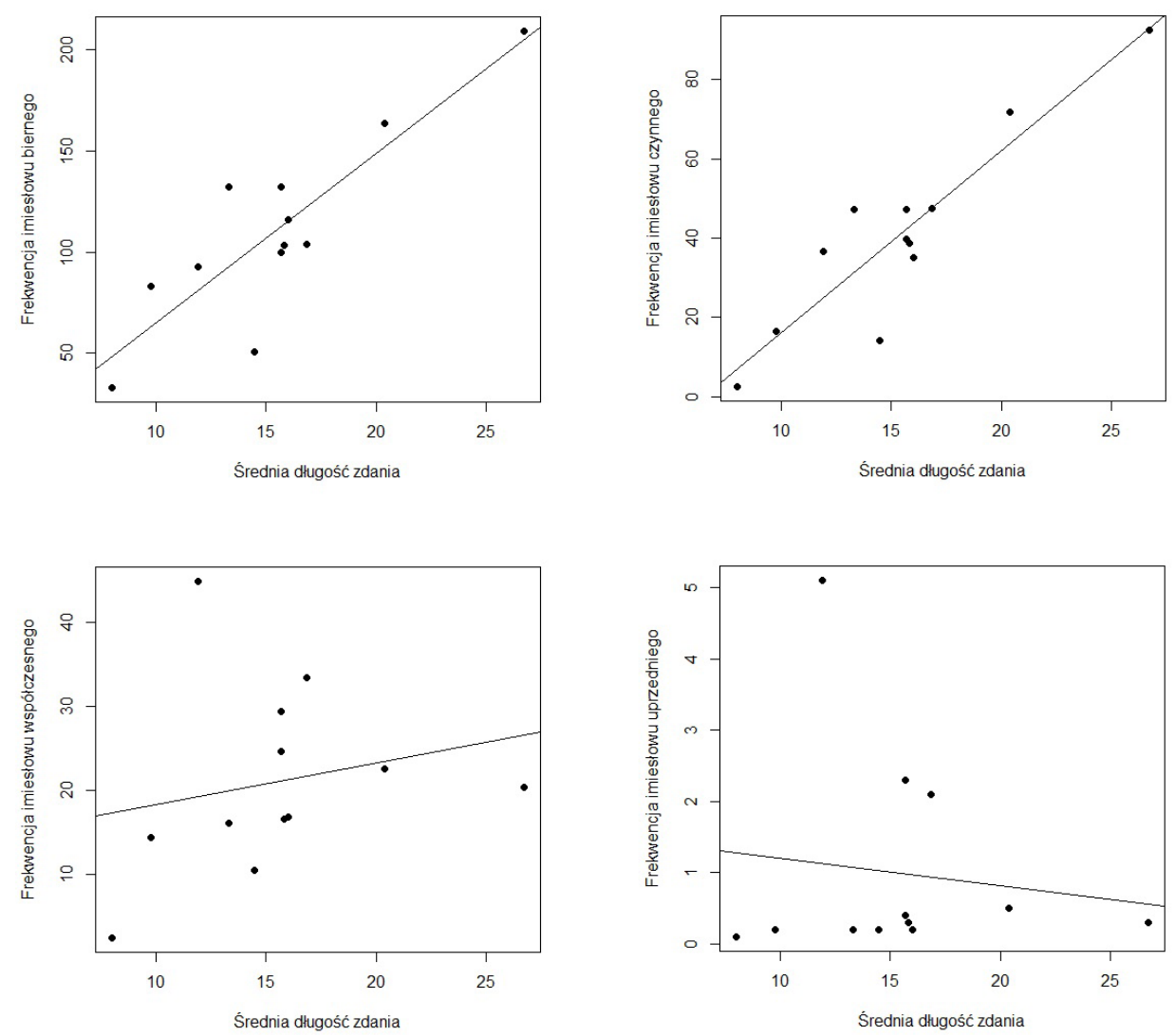

Rysunek nr 6. Wykresy frekwencji imiesłowów (na 10000 słów) i średniej długości zdania. 
Jak widać z powyższych danych, dla imiesłowów przymiotnikowych zachodzi mocna dodatnia korelacja liniowa, natomiast dla imiesłowów przysłówkowych korelacja ta jest słaba lub w ogóle jej nie ma.

\section{Dyskusja}

Badanie 1 pokazało zależność pomiędzy formalnością stylu a częstością występowania w nim imiesłowów oraz fakt, że imiesłowy przymiotnikowe częściej występują w tekstach informacyjnych, a przysłówkowe w fikcjonalnych. Pytanie brzmi, jaki związek zachodzi pomiędzy tymi danymi a długością zdania. Nie zaskakuje, że formalne style użytkowe zawierają zdania statystycznie dłuższe niż nieformalne użytkowe, a więc istnienie silnej korelacji pomiędzy średnią długością zdania w stylach a frekwencją w nich imiesłowów przymiotnikowych wydaje się dość intuicyjne. Natomiast długość zdań w tekstach literackich bywa bardzo zróżnicowana; średnia długość zdania nie jest tam duża - jednak to w literaturze imiesłowów przysłówkowych jest najwięcej. $Z$ drugiej strony Badanie 3 pokazuje, że ogólna zależność pomiędzy długością zdania a frekwencją imiesłowów przysłówkowych jednak istnieje. Jak to wytłumaczyć?

Poświęcę najpierw trochę więcej uwagi samej hipotezie dotyczącej długości zdania, która zakłada bezpośredni, a nie pośredni związek pomiędzy długością zdania a frekwencją imiesłowów. Wyjściowa hipoteza tego artykułu odnośnie do czynników kształtujących dystrybucję zakłada, że imiesłowy pozwalają na skondensowane, skrótowe wyrażenie treści - pominięcie spójników zdań podrzędnych i (w przypadku imiesłowów przymiotnikowych) większą prostotę składniową zdań długich: zamiast dodatkowego zdania podrzędnego występuje bardziej rozbudowana grupa nominalna. Imiesłowy przysłówkowe nie czynią co prawda struktury zdania bardziej płaską, mogą natomiast posłużyć do jej zróżnicowania, a więc uczynić ją bardziej estetyczną. Poniżej prezentuję dwa przykłady zaczerpnięte z NKJP i przekształcone następnie przeze mnie dla unaocznienia tych funkcji imiesłowów.

Przykład 3: Wielokrotnie złożone zdanie, które traci nieco na jasności po przekształceniu imiesłowów na czasowniki osobowe.

Miasteczko pospiesznie zbierało się do snu, jak zwykle w porze deszczowej, by zdążyć ze wszystkim przed burzą, która dojrzewała na ciemniejącym niebie w spęczniałych, gniewnych chmurach, czekając tylko zmroku, żeby dać upust złości nagromadzonej podczas upalnego dnia.

(Wojciech Jagielski, Nocni wędrowcy, 2009 r., źródło: NKJP)

Miasteczko pospiesznie zbierało się do snu, jak zwykle w porze deszczowej, by zdążyć ze wszystkim przed burzą, która dojrzewała na niebie, które ciemniało, w spęczniałych, gniewnych chmurach i która czekała tylko zmroku, żeby dać upust złości nagromadzonej podczas upalnego dnia.

W powyższym przykładzie widać, że w szczególności imiesłów przymiotnikowy pozwala wyeliminować nieporęczną ,watę słowną" i zamieszanie wynikające ze 
sporej liczby podmiotów. Można przy tym to zdanie doprowadzić do stanu całkowicie poprawnego składniowo i stylistycznie, eliminując jeden spójnik zdania względnego, drugi podmieniając na bardziej archaiczny i stosując inwersję dla zwiększenia jasności:

Miasteczko pospiesznie zbierało się do snu, jak zwykle w porze deszczowej, by zdążyć ze wszystkim przed burzą, która na niebie, co ciemniało, dojrzewała w spęczniałych, gniewnych chmurach i czekala tylko zmroku, żeby dać upust złości nagromadzonej podczas upalnego dnia.

Tak brzmiące zdanie zyskuje wręcz na poetyczności i dramatyzmie. Jednakże konieczność sięgnięcia po archaizację i inwersję, czyli nietypowe, ,poetyckie” właśnie środki, oraz rozbicia jednego zdarzenia (,,burza dojrzewa”) na dwa osobne (,niebo ciemnieje” i ,burza dojrzewa”) pokazuje, że imiesłowy przymiotnikowe rzeczywiście kondensują informację i upraszczają składnię. Jeśli przykład ten nie jest wystarczająco przekonujący, spójrzmy na jeszcze jedno zdanie:

Przykład 4: Wielokrotnie złożone zdanie, które traci na jasności po przekształceniu imiesłowów na czasowniki osobowe.

Zachwycony pięknością bożego świata, pochwycił nieodstępne skrzypki i zasiadłszy na próchniejącym pniu starej jakiejś olchy, patrząc $w$ jasnobłękitne niebo i słuchając tajemniczych głosów z głębin jego brzmiących, wylewał serdeczną muzyką przepełniające duszę błogie uczucia.

(Hanna Kostyrko, Klechdy domowe, 1960 r., źródło: NKJP)

Zachwycony pięknością bożego świata, pochwycił nieodstępne skrzypki i po tym, jak zasiadł na pniu starej jakiejś olchy, który próchnial, kiedy patrzył w jasnobłękitne niebo i słuchal tajemniczych głosów, które brzmiały z jego głębin, wylewał serdeczną muzyką błogie uczucia, które przepelniały duszę.

W tym wypadku rodzi się pytanie, czy ,„próchniejący” to jeszcze imiesłów, czy już przymiotnik. Niezależnie od rozstrzygnięcia zdanie to pokazuje, że zarówno imiesłowy przysłówkowe, jak i przymiotnikowe mogą kondensować informację i zwiększać klarowność zdań długich. Imiesłów bierny pozostawiłam bez zmiany, gdyż zamiana strony biernej na czynną wymagałaby jeszcze głębszej przebudowy zdania - samo zdanie co prawda tym bardziej straciłoby na klarowności, ale wraz z nim straciłby ją i sam przykład, gdyż zamiana strony biernej na czynną pociąga za sobą szereg zjawisk semantycznych, które nie stanowią przedmiotu tego artykułu.

Wróćmy jednak do Badań 3 i 4 oraz postawionego wyżej pytania. Wydawałoby się, że skoro imiesłowy przymiotnikowe mają własność upraszczania struktury składniowej zdania, lepiej nadają się do zwiększania klarowności zdań długich. Jednak zarówno imiesłowy przymiotnikowe, jak i przysłówkowe posiadają pewne zalety w zakresie kondensacji i zwiększania klarowności tekstu, jak pokazuje to przykład 4; Badanie 3 pokazuje zaś, że prawdopodobieństwo, że dowolne słowo będzie imiesłowem, przyrasta zarówno dla imiesłowów przymiotnikowych, jak i przysłówkowych. Dlaczego nie przekłada się to na kwestię dystrybucji imiesłowów przysłówkowych w stylach?

Przypuszczam, że imiesłowy przysłówkowe są tak nacechowane stylistycznie, że ich dystrybucja w stylach jest warunkowana nie tylko ich przydatnością w zdaniach 
długich, ale jeszcze wieloma innymi czynnikami. Mimo że efekt sam w sobie istnieje, nie jest on czynnikiem determinującym dystrybucję, gdyż nakładają się na niego jeszcze inne zjawiska. Mogą istnieć style, w których zdania o danej długości częściej zawierają imiesłowy niż zdania o podobnej długości w pozostałych stylach, nawet jeśli jednocześnie zawierają je rzadziej niż zdania dłuższe od nich w obrębie tego samego stylu. Sprawdzenie tego wymagałoby jednak przeprowadzenia jeszcze jednego badania na korpusie większym niż milionowy, więc to wyjaśnienie musi pozostać na razie zwykłym domniemaniem.

Należy tutaj zauważyć, że styl jest zależny przede wszystkim od konwencji. Pytanie o przyczyny takiego, a nie innego rozkładu imiesłowów w poszczególnych stylach jest ciekawe, gdyż jest pytaniem o funkcję tych form: co takiego niosą ze sobą, co okazuje się użyteczne w niektórych sytuacjach komunikacyjnych, a balastem w pozostałych. Jest to także poniekąd pytanie o ich naturę. Złudne jednak wydaje się założenie, że możemy w pełni objaśnić dystrybucję danej formy gramatycznej w różnych stylach językowych poprzez wyszczególnienie zamkniętej grupy precyzyjnie zdefiniowanych i policzalnych czynników.

K. Bojałkowska (2006a) pisze, że imiesłowy przysłówkowe cechują się wyższą frekwencją $\mathrm{w}$ tekstach tłumaczonych $\mathrm{z}$ języka angielskiego niż oryginalnie polskich. Badaczka łączy to z potrzebą oddania w przekładzie typowych dla języka angielskiego względnych stosunków czasowych. Irena Tabakowska (1967) zauważa zaś, że konstrukcje imiesłowowe z imiesłowami przysłówkowymi są przyswajane przez dzieci z dużym trudem, dopiero w wyższych klasach szkoły podstawowej:

\footnotetext{
Już samo tworzenie imiesłowów wymaga pewnych umiejętności i zachowania właściwych rygorów gramatycznych: imiesłów współczesny tworzy się od czasowników niedokonanych, imiesłów uprzedni od dokonanych, wybór zaś właściwego aspektu czasownika nie jest obojętny dla treści wypowiedzi [...]. Ponadto chodzi tu o czasy tzw. względne [...]. Dlatego też dzieci szkolne stosunkowo późno i nie bez trudu przyswajają sobie te konstrukcje.
}

Czyli imiesłowy zawierałyby w sobie cechy czyniące je inherentnie trudniejszymi dla użytkownika języka polskiego - w przypadku imiesłowów przysłówkowych byłby to przede wszystkim brak analogii do innych form, ponieważ wyrażanie względnych stosunków czasowych za pomocą środków gramatycznych nie jest typowe dla języka polskiego i, jak pisała Barbara Bartnicka (patrz: sekcja 2), czasy względne zanikły już w przypadku imiesłowów przymiotnikowych, gdzie wcześniej też występowały.

Jest też możliwe alternatywne, ale niesprzeczne wyjaśnienie. Zakłada ono istnienie sprzężenia zwrotnego pomiędzy trudnością wynikającą z czasów względnych (a więc braku analogii imiesłowów przysłówkowych do innych form czasownikowych) a trudnością biorącą się z nieczęstego i późno wyuczonego posługiwania się imiesłowami. Wracamy tutaj do Badań 1 i 2. Otóż dzieci odczuwają imiesłowy przysłówkowe jako trudne także dlatego, iż nie mają z nimi styczności w pierwszych latach życia, w języku mówionym. Jeżeli już, to spotykają się z quasi-imiesłowami, które nie są zgodne z normą tożsamości podmiotów i czasu względnego (por. wyniki Badania 2). Właściwe imiesłowy 
przysłówkowe poznają dopiero wtedy, gdy po raz pierwszy zetkną się z językiem pisanym i formalnym, a mają już wtedy ukształtowaną bazę pod błędne nawyki poprzez analogię z quasi-imiesłowami. Wyższa frekwencja imiesłowów w stylach formalnych, a także fakt, że imiesłowy przymiotnikowe występują częściej w tekstach informacyjnych, a przysłówkowe w fikcjonalnych, zależałyby zatem również od czynnika kulturowego, czyli nawyków komunikacyjnych od początku wiążących użycie imiesłowów z pewnymi konwencjami stylistycznymi. Tak, imiesłowy są trudne - jednakże dzieje się tak może przede wszystkim dlatego, że rzadko się nimi posługujemy. Rzadko się nimi zaś posługujemy, bo późno je sobie przyswajamy i jesteśmy przyzwyczajeni do bardzo specyficznych kontekstów użycia.

Warto także nadmienić, że imiesłowy przysłówkowe, w przeciwieństwie do przymiotnikowych, cechują się pewną płynnością znaczenia - czasem trudno ustalić, czy imiesłów wyraża relację czysto czasową, czy też np. przyczynową ${ }^{6}$. To może w naturalny sposób ograniczać ich przydatność w tekstach wymagających wielkiej precyzji, na przykład naukowych lub legislacyjnych. Byłoby to ograniczenie funkcjonalne innego rodzaju. W literaturze z kolei taka wieloznaczność nie stanowi raczej przeszkody, tak samo jak wadą nie jest niecodzienność imiesłowów - kojarzy się raczej z ambicją i wyszukaniem stylu.

Podsumowując: można domniemywać, że w przypadku imiesłowów przysłówkowych inne czynniki znoszą nieco oddziaływanie badanego czynnika funkcjonalnego, tj. zależności od długości zdania. Najważniejszym z czynników może być ich ogólna rzadkość, która narasta na zasadzie sprzężenia zwrotnego. Imiesłowy przysłówkowe uprzednie, jak wielokrotnie obserwowano wcześniej i jak pokazuję też w tym artykule, nie tylko są rzadkie, lecz wręcz zanikają. Zatem dla częstszych i mniej nacechowanych stylistycznie imiesłowów przymiotnikowych długość zdania byłaby czynnikiem determinującym dystrybucję, a dla imiesłowów przysłówkowych - nie, gdyż byłby to tylko jeden z czynników wywierających na nią wpływ.

\section{Podsumowanie}

W artykule zbadano i opisano dystrybucję imiesłowów przysłówkowych w stylach funkcjonalnych wyróżnionych w Narodowym Korpusie Języka Polskiego. Okazało się, że częstość występowania imiesłowów jest ściśle powiązana z formalnością danego stylu. Co więcej, imiesłowy przysłówkowe występują głównie w tekstach fikcjonalnych, a przymiotnikowe w informacyjnych. Jedną z przyczyn różnej dystrybucji imiesłowów w różnych typach funkcjonalnych jest także zależność pomiędzy długością zdania a częstością występowania imiesłowów. Prawdopodobieństwo, iż dowolne słowo

${ }^{6}$ Np. Pędzac na oślep przed siebie, Ania pogubiła rzeczy z torby - to zdanie oznacza, że Ania pogubiła rzeczy podczas biegu; może jednak być też zrozumiane w taki sposób, że Ania pogubiła rzeczy nie tylko podczas, ale i z powodu biegu; gdyby szła spokojnie, rzeczy nie powypadałyby jej z otwartej torby (przykład wymyślony). 
w zdaniu będzie imiesłowem, wzrasta wraz z długością zdania. Zjawisko to przekłada się na różną dystrybucję imiesłowów w różnych stylach funkcjonalnych. Dotyczy to jednak tylko imiesłowów przymiotnikowych, natomiast nie da się dostrzec podobnego związku z dystrybucją imiesłowów przysłówkowych.

Prawdopodobnie zależy to od kilku czynników, a w szczególności od silniejszego w przypadku imiesłowów przysłówkowych oddziaływania sprzężenia zwrotnego związanego z niecodziennością tychże form; niecodzienność ta miałaby swój korzeń w nietypowości czasów względnych w polszczyźnie, ale narastałaby za sprawą wyuczonych nawyków i konwencji komunikacyjnych - formy rzadko używane sprawiają więcej trudności niż te używane częściej, co z kolei powoduje, że użytkownik sięga po nie w szczególnych sytuacjach komunikacyjnych wymagających skupienia na doborze słów, a same formy postrzegane są jako specyficznie nacechowane.

Frazeologizmy imiesłowowe stanowią znaczący procent form oznaczonych w korpusie jako imiesłowy przysłówkowe uprzednie. W połączeniu z obserwacją, że liczba imiesłowów uprzednich znacząco zmalała w literaturze współczesnej w porównaniu z literaturą piękną przed 1950 r. (jedyne starsze źródła w NKJP), fakt ten stanowi kolejny argument na rzecz tezy, że imiesłowy przysłówkowe uprzednie zanikają w polszczyźnie.

\section{Bibliografia}

Bartnicka B., 1970, Adiektywizacja imiesłowów w języku polskim, Warszawa.

Bellert I., 1977, On semantic and distributional properties of sentential adverbs, Linguistic Inquiry VIII, s. $337-351$.

Birzer S., 2012, From subject to subjectivity: Russian discourse structuring elements based on the adverbial participle govorja 'speaking', Russian Linguistics XXXVI/3, s. 221-249.

Birzer S., 2015, Generally speaking, connectivity and conversation management combined: the functions of Russian voobšče govorja and Polish ogólnie mówiąc, Russian Linguistics XXXIX/1, s. 81-115.

Birzer S., 2016, Assessing the role of pattern and matter replication in the development of Polish komentarze metatekstowe based on infinite verba dicendi (online: https://www.academia.edu/10966631/ Assessing_the_role_of_pattern_and_matter_replication_in_the_development_of_Polish_komentarze metatekstowe_based_on_infinite_verba_dicendi (dostęp: 26.09.2019 r.)).

Bogusławski A., 1978, Towards an operational grammar, Studia Semiotyczne VIII, s. 29-90.

Bogusławski A., 1988, Preliminaria gramatyki operacyjnej, Polonica XIII, s. 163-223.

Bojałkowska K., 2006a, Imiesłów przysłówkowy jako składnik konstrukcji zdaniowej, Acta Universitatis Nicolai Copernici, Filologia Polska LXII, s. 53-68.

Bojałkowska K., 2010, Opis składniowy imiesłowów przysłówkowych we współczesnym języku polskim, Torun.

Burska K., 2016, Analityzmy leksykalne i ich syntetyczne odpowiedniki w prasie, Łódź.

Buttler D., Kurkowska H., Satkiewicz H., 1986, Kultura języka polskiego. Zagadnienia poprawności gramatycznej, Warszawa.

Buttler D., Kurkowska H., Satkiewicz H., 1987, Kultura języka polskiego. Zagadnienia poprawności leksykalnej, Warszawa.

Eder M., Górski R.L., Król M., 2019, Zmiana w języku. Studia kwantytatywno-korpusowe, Kraków.

Gajda S., 2012b, Stylistyka integrująca, Poradnik Językowy, nr 6, s. 56-66. 
Górski R.L., Łaziński M., 2012, Typologia tekstów w NKJP. Narodowy Korpus Języka Polskiego, [w:] Narodowy Korpus Języka Polskiego, red. A. Przepiórkowski, M. Bańko, R.L. Górski, B. Lewandowska-Tomaszczyk, Warszawa, s. 13-23.

Greenacre M.J., 2010, Correspondence Analysis, Interdisciplinary Reviews, Computational Statistics XXV, s. 613-619.

Grochowski M., 1984, Składnia wyrażeń polipredykatywnych (Zarys problematyki), [w:] Gramatyka współczesnego języka polskiego. Składnia, red. Z. Topolińska, Warszawa, s. 213-299.

Jadacka H., 2005, Kultura języka polskiego. Fleksja, słowotwórstwo, składnia, Warszawa.

Klebanowska B., 1982, Przyimek PO w znaczeniu czasowym, Prace Filologiczne XXXI, s. 97-102.

Kubicka E., 2017, Jak mówimy, jakoś mówiąc? Formalne i semantyczne właściwości adwerbialnych uzupełnień quasi-imiesłowowego mówiąc, LingVaria XII, nr 1 (23), s. 99-113.

Kubicka E., 2018, Czy mówiąc prostszym językiem, mówimy prościej? Formalnie narzędnikowe frazy charakteryzujące mówienie, LingVaria XIII, nr 1 (25), s. 79-90.

Moroz A., 2007, Uwagi o ciągach parentetycznych z segmentem mówiąc, [w:] Studia nad słownictwem dawnym i współczesnym języków słowiańskich, red. J. Kamper-Warejko, I. Kaproń-Charzyńska, J. Kulwicka-Kamińska, Toruń, s. 187-194.

Niehüser W., 1987, Redecharakterisierende Adverbiale, Göppingen.

Pęzik P., 2012, Wyszukiwarka PELCRA dla danych NKJP, [w:] Narodowy Korpus Języka Polskiego, red. A. Przepiórkowski, M. Bańko, R.L. Górski, B. Lewandowska-Tomaszczyk, Warszawa, s. 253-273.

Stępień M., 2014, Wyrażenia parentetyczne w strukturze wypowiedzi - właściwości semantyczne, składniowe, prozodyczne, Warszawa.

Stępień M., 2017, Walencja czasowników a problem dziedziczenia własności walencyjnych przez quasiimiesłowy przysłówkowe, Prace Filologiczne LXX, s. 411-432.

Szober S., 1959, Człowiek współczesny w zwierciadle języka, [w:] Tenże, Wybór pism, Warszawa, s. 345-353.

Tabakowska I., 1967, Oznajmienia imiesłowowe w języku pisanym uczniów starszych klas szkoły podstawowej na Śląsku, Język Polski XLVII, s. 128-138.

Wajszczuk J., 1997, System znaczeń w obszarze spójników polskich: Wprowadzenie do opisu, Warszawa.

Wajszczuk J., 2005, O metatekście, Warszawa.

Wierzbicka A., Wierzbicki P., 1968, Praktyczna stylistyka, Warszawa.

Wróbel H., 1975, Składnia imiesłowów czynnych we współczesnej polszczyźnie, Katowice.

\section{STRESZCZENIE}

Słowa kluczowe: polskie imiesłowy, style funkcjonalne, analiza kwantytatywna, quasi-imiesłowy, długość zdania.

W artykule zbadano metodami kwantytatywnymi dystrybucję imiesłowów i quasi-imiesłowów w stylach funkcjonalnych języka polskiego wyróżnionych w NKJP. Dane pokazują zależność pomiędzy częstością występowania imiesłowów a formalnością stylu. Zaobserwowano także mocną korelację dodatnią pomiędzy średnią długością zdania w stylach a częstością występowania imiesłowów przymiotnikowych. Frekwencja wszystkich czterech imiesłowów rośnie wraz z długością zdania, jednak jedynie w przypadku imiesłowów przymiotnikowych długość zdania wpływa na dystrybucję w stylach. Dane potwierdzają także zanikanie imiesłowów uprzednich i pokazują, że tzw. quasi-imiesłowy uprzednie stanowią liczący się odsetek współczesnych użyć imiesłowów uprzednich. 


\section{SUMMARY}

\section{Polish participles: distribution and sentence length across functional styles. Quantitative analyses}

Keywords: Polish participles, functional styles, quantitative analysis, quasi-participles, sentence length.

The distribution of four Polish participles across different functional styles has been discussed in many works, but never treated as an independent topic. This paper aims to examine the frequency of participles (both adjectival and adverbial) in 12 styles represented in the National Corpus of Polish Language (NKJP) and to provide some explanations for the varied distribution of these forms. It is done in the course of several quantitative analyses. The difference between adverbial participles and so-called quasi-participles is also taken into consideration.

The data presented shows the direct correlation between the frequencies of every participle type and the formality level of a particular style. The difference between adverbial participles and quasi-participles is demonstrated as significant. The article provides new arguments for the thesis that anterior adverbial participles tend to disappear in Polish.

Interestingly, there is also a very strong positive correlation between average sentence length across styles and the associated frequencies of adjectival participles, however it only concerns this particular group. The data for adverbial participles does not reflect this pattern. What is more, the probability that a word in a sentence is a participle is found to be growing along with sentence length for all four types of participles when the style division is not considered. It suggests that the origin of adverbial participles' style distribution is more multifactorial than that of adjectival participles. It seems that all four participles are efficient grammar means to maximize the amount of information in a sentence by compacting additional verbal groups, but the adverbial participles also bear some other characteristics (i.e. relative tense marking, some vagueness of meaning) that could supposedly shape their functionality across styles. 